\title{
Analysis of the chemical quality of underground waters in the municipality of Dassa-zoumè
}

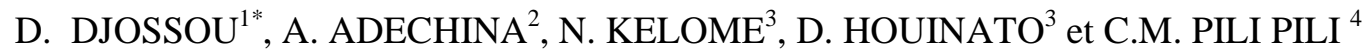 \\ ${ }^{1}$ Département d'Odontologie, Faculté des Sciences de la Santé, BP 188 Cotonou, République du Bénin. \\ ${ }^{2}$ Département des Sciences de la Terre, Université d'Abomey-Calavi, 72 BP 50 Cotonou, République du Bénin. \\ ${ }^{3}$ Département des Sciences de la Terre, Université d'Abomey-Calavi, O1 BP 526 Cotonou, \\ République du Bénin. \\ ${ }^{3}$ Laboratoire d'Epidémiologie des Maladies Chroniques et Neurologiques, Faculté des Sciences de la Santé du \\ Bénin, BP 188 Cotonou, République du Bénin. \\ ${ }^{4}$ Médecine Dentaire et Stomatologie, UCL-Faculté de Médecine et Médecine Dentaire, Cliniques \\ Universitaires St-Luc, Bruxelles, Belgique. \\ "Corresponding author; E-mail: cabinetdjossou@gmail.com
}

\begin{abstract}
In some parts of Benin, like in many African countries, the fluorine rates contained in waters are higher than the rate recommended by the World Health Organization (WHO) (0.7-1.5 mg- /- L). Fluorine is useful against dental caries and makes the tooth enamel stronger. Nevertheless, at a higher concentration, it stains on teeth, weakens bones or causes focal points that may eventually lead to deforming joint arthritis: fluorosis. The aim of this study was to contribute to the assessment of the quality of borehole water in the municipality of Dassa-Zoumè where fluorine contaminations had been proven. The multiparameter tool was used for the in-situ measurement of the physical and chemical parameters of the waters which were sampled. The concentrations of $\mathrm{Ca}^{2+}, \mathrm{NH}^{4+}, \mathrm{NO}_{3}^{-}, \mathrm{NO}_{2}^{-}$and $\mathrm{F}^{-}$were determined by an ionic liquid chromatography and a spectrophotometer in the National Hydraulics Laboratory in Benin. The water quality was assessed according to the standards prescribed by WHO in 2002 and enacted in the Republic of Benin. Statistical analyses for $\mathrm{p}<0.05$ have not shown any correlation between $\mathrm{F}^{-}$and the four elements $\left(\mathrm{Ca}^{2+}, \mathrm{NO}_{3}^{-}, \mathrm{NH}^{4+}, \mathrm{NO}_{2}^{-}\right)$. But correlation appears with an increase in $\mathrm{pH}$ ranging from 6.4 to 7.08 for an average of 6.83 . Generally, only waters of the Akofodjoule district are all contents below the WHO standard for consumable water. The calcium content is also below standard.
\end{abstract}

(c) 2015 International Formulae Group. All rights reserved.

Keywords: Drinking water, fluorine, Bénin.

\section{INTRODUCTION}

Water is the source of life; but it can also cause illness and even death. In Benin, underground water is a major source of drinking water especially in urban areas. Nowadays, supply of drinking water, is one of the major concerns of the population. $70 \%$ of them use water for domestic purposes from wells or public boreholes (WHO, 2002). Indeed, in many parts of Benin, people are confronted with the problems of quality as well as of quantity of water. In the past, 
quality problems were related to microbiological hazards. Today, there are additional chemical hazards whose origins are diverse and multiple (Dovonon et al., 2011).

Fluorine is a useful trace element against dental caries and it hardens tooth enamel but it is harmful to human health when consumption exceeds the accepted threshold (Ene, 2014; Craig et al., 2015). It is proven that drinking water is the main source of fluorine in the human body. As such, according to the WHO (WHO, 2002) guideline, the maximum contents of fluorine in drinking water are about $1.5 \mathrm{mg} / \mathrm{l}$. The excessive concentration noticed in most underground waters is fundamentally linked to the mineralogical composition of the rock. The dissolution of minerals causes the release of fluorine into the water (Cairncross, 1993; Arif et al., 2013). Non-organic fluorides are very irritating and toxic, while organic fluorides are generally less toxic. The toxic effects of fluoride on humans comprise: sclerosis, ligament calcification, stains on teeth, osteoclerosis, anorexia, anemia and growth impairment (Bronckers et al., 2009; Ygezu, 2013).

A survey conducted between 2006 and 2007 found that of 1,129 people surveyed, 312 are suffering from dental fluorosis, that is $27.63 \%$ of the people (Dovonon et al., 2011).

This paper investigates the level of fluorine in borehole water from drilling basement areas of the region of Zou and Les Collines which are rich in fluoride and specifically the municipality of Dassa-Zoumè in order to prevent damage that may be caused by these waters.

\section{MATERIALS AND METHODS}

\section{Area of study}

The study was be conducted in the municipality of Dassa-Zoumè-Zoumé, one of the six municipalities of the department of 'Collines'.The surface of area is $1,711 \mathrm{~km}^{2}$ (INSAE, 2002). It represents $1.52 \%$ of the whole national territory. It is surrounded by the municipality of Glazoué in the North, the municipalities of Djidja, Covè and Zagnanado in the South, the municipalities of Savè and Kétou in the East and by the municipality of Savalou in the West (Figure 1). The municipality of Dassa-Zoumè is divided into ten (10) districts, with a population of 93,967 inhabitants (INSAE, 2002). The hydrography is regular with quite pronounced low flows. It rains from August to October. Besides Ouémé, the largest river in the country, DassaZoumè is drained by streams. They are seasonal rivers which are tributaries or subtributaries to the Ouémé River. They are: Okrou which marks the borders with Savalou; Kossi in the North-East; Loto and Etéwi flow within the municipality. The subsoil is mainly composed of metamorphic rocks such as migmatites, gneisses, of orthogneissified porphyritic granites with mega feldspar crystals called Dassa-Zoumè-Zoumè. The latter contain thin and half-grey granites in the same position as those of Tré, Gbowèlè (Egboou, 2008).

\section{Water sampling and analysis}

A Preliminary work of random selection of 24 wells and boreholes was done by the Epi 6 software. The fieldwork took place in two phases: the first was a prospective visit to the field. In the second phase, the physical and chemical parameters of the water (electric conductivity, temperature, $\mathrm{pH}$ ) were measured in-situ using a multiparameter tool of Combo HANNA brand (combo pH \& EC). The water was then sampled into $1,000 \mathrm{ml}$ polyethylene bottles. Once rinsed in-situ, filled with water and sealed, the bottles were conditioned at about 4 ${ }^{\circ} \mathrm{C}$ in a cold cooler and conveyed promptly to laboratory. The sampling is done in dry season. Laboratory analysis focused on $\mathrm{Ca}^{2+}$, $\mathrm{NH}^{4+}, \mathrm{F}^{-}, \mathrm{NO}_{3}^{-}, \mathrm{NO}_{2}^{-}$elements that are measured out by an ionic liquid chromatography and a spectrophotometer. 


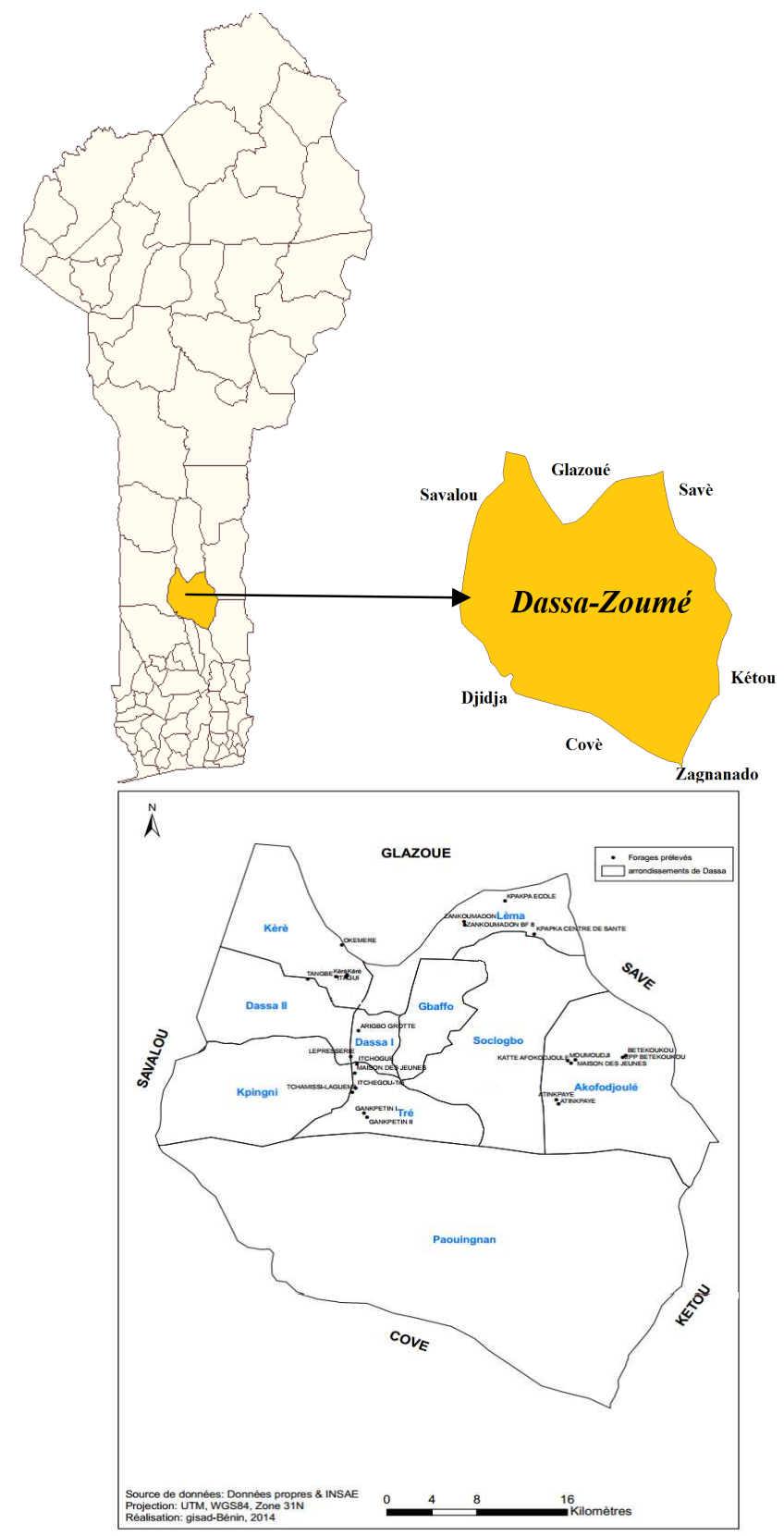

Figure 1: Map showing the sampling points.

\section{Statistical analysis}

Differences in proportions were analyzed using chi-square test. The statistical relationship among the parameters measured in-situ and the major and minor elements is determined from the correlation coefficient for $\mathrm{p}<0.05$ considered significant. The statistical calculations were also performed using SPSS version 13.0 


\section{RESULTS}

\section{In situ physical and chemical parameters of waters}

The $\mathrm{pH}$ ranged from 6.4 to 7 with an average of 6.8. Temperatures ranged from $29.1{ }^{\circ} \mathrm{C}$ to $30.9^{\circ} \mathrm{C}$ with an average of 29.6 ; values vary slightly from one site to another and from one district to another. Conductivities waver between 418 and to 1408 Siemens /s. Besides the district of Lema where the waters are very conductive, the average conductivity of the other four districts is slightly about an average of 764.52 Siemens/s (Figure 2).

\section{Variation of major elements in waters}

The levels range from:

41.7 to $189.3 \mathrm{mg} / \mathrm{l}$ with an average of 103.5 $\mathrm{mg} / \mathrm{l}$ for $\mathrm{Ca}^{2+}$

0 to $147.4 \mathrm{mg} / \mathrm{l}$ with an average of $52.8 \mathrm{mg} /$ 1 for $\mathrm{NO}^{-}$

0 to $1.7 \mathrm{mg} / 1$ with an average of $0.3 \mathrm{mg} / 1$ for $\mathrm{NH}_{4}^{+}$

From 0 to $1.6 \mathrm{mg} / 1$ with an average of 0.2 $\mathrm{mg} / 1$ for $\mathrm{NO} 2$

Referring to Decree No. 2001-094 of 20th February 2001 laying down standards in the Republic of Benin, waters in each of the nine sampling points have contents of $\mathrm{Ca}^{2+}$, $\mathrm{NO}^{-}, \mathrm{NO}^{-}$that are not safe for consumption. They represent $37,5 \%$ of all sites. As for $\mathrm{NH}_{4}{ }^{+}$, standards are exceeded in 5 waterworks representing $20,8 \%$ of the sites.

The water quality assessment in the five districts has led to the conclusion that the waters from the districts of Lema, Tré and Dassa-Zoumè 1 have an average quantity of calcium that exceeds the accepted norm for drinking water. The waters from the districts of Akofodjoulè and Lema have nitrate rates above the accepted standard while the nitrite rates are exceeded in the districts of Tré, Lema and Dassa1. Only waters from Lema revealed ammonium rates exceeding the accepted standard (Figures 3 and 4).

\section{Fluorine variation in waters}

From Figure 5, we can see that waters from 12 waterworks have contents exceeding $1.5 \mathrm{mg} / \mathrm{l}$, it means $57 \%$ of the sites. The contents fluctuate between 0.3 and $4.3 \mathrm{mg} / \mathrm{l}$ with an average of $1.9 \mathrm{mg} / \mathrm{l}$. All the sampled waters from boreholes in the districts of Dassa-Zoumè 1, Tré, and some samples from Kéré (Okéméré, Tangbé) and Lèma (Zankoumadon) are not safe for consumption. Those from the district of Akofodjoulé are below standard and therefore could be consumed (Figure 5).

\section{Correlation of data}

From the statistical analysis of the data measured in-situ and those from the laboratory; it appears that only the $\mathrm{pH}$ could be correlated with levels of fluorine in waters with a $\mathrm{pH}$-value of 0.03 . However, in the district of Akofodjoulé, where waters are safe for drinking, low $\mathrm{pH}$ values and temperatures are recorded, with conductivity approaching the average of all samples (Table 1). In this district, the $\mathrm{Ca}^{2+}$, contents of all waters are also below standard. Only nitrate contents exceed the accepted standards in the Republic of Benin.

Table 1: Norm for the elements in water consumption in the Republic of Benin.

\begin{tabular}{lc}
\hline Elements & Threshold (mg/l) \\
\hline $\mathrm{Ca}^{2+}$ & 100 \\
$\mathrm{NO}^{-}$ & 45 \\
$\mathrm{NH}^{+}$ & 0.5 \\
$\mathrm{NO} 2^{-}$ & 0.1 \\
$\mathrm{~F}$ & 1.5 \\
\hline \multicolumn{2}{c}{ Dovonon et al. (2011) }
\end{tabular}


D. DJOSSOU et al. / Int. J. Biol. Chem. Sci. 9(5): 2735-2742, 2015

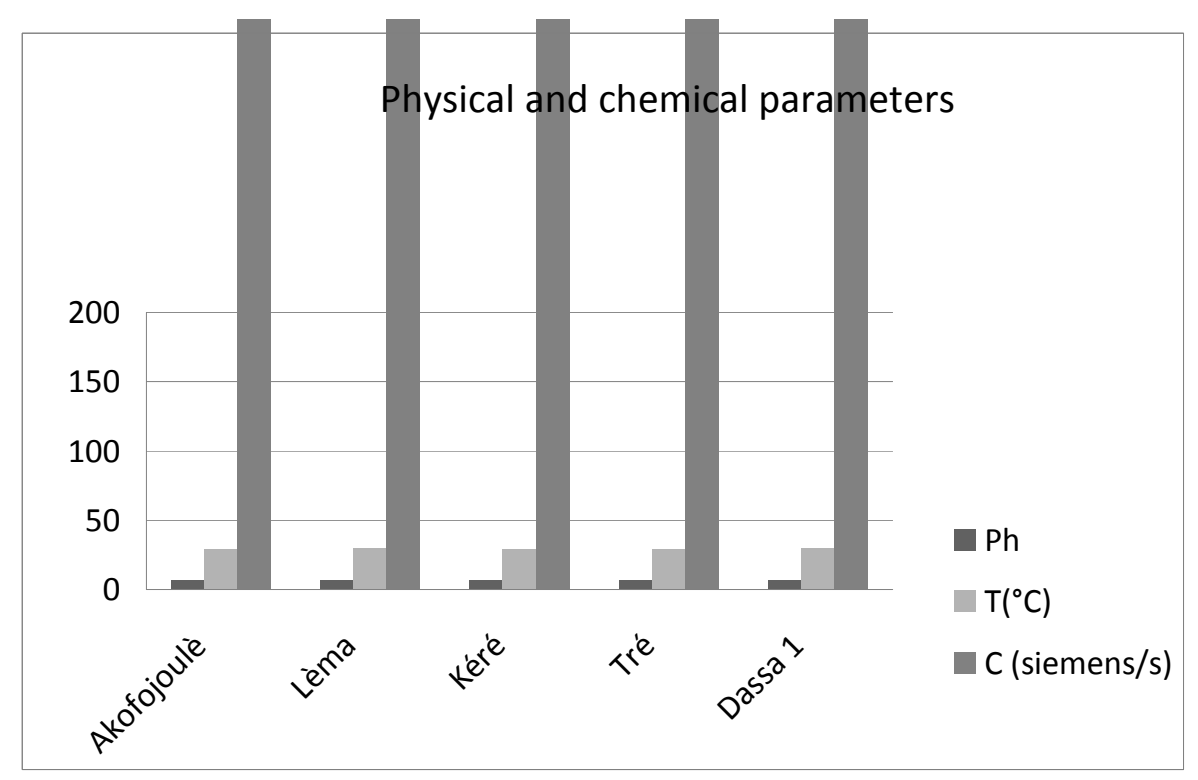

Figure 2: Physical and chemical parameters as measured in situ.

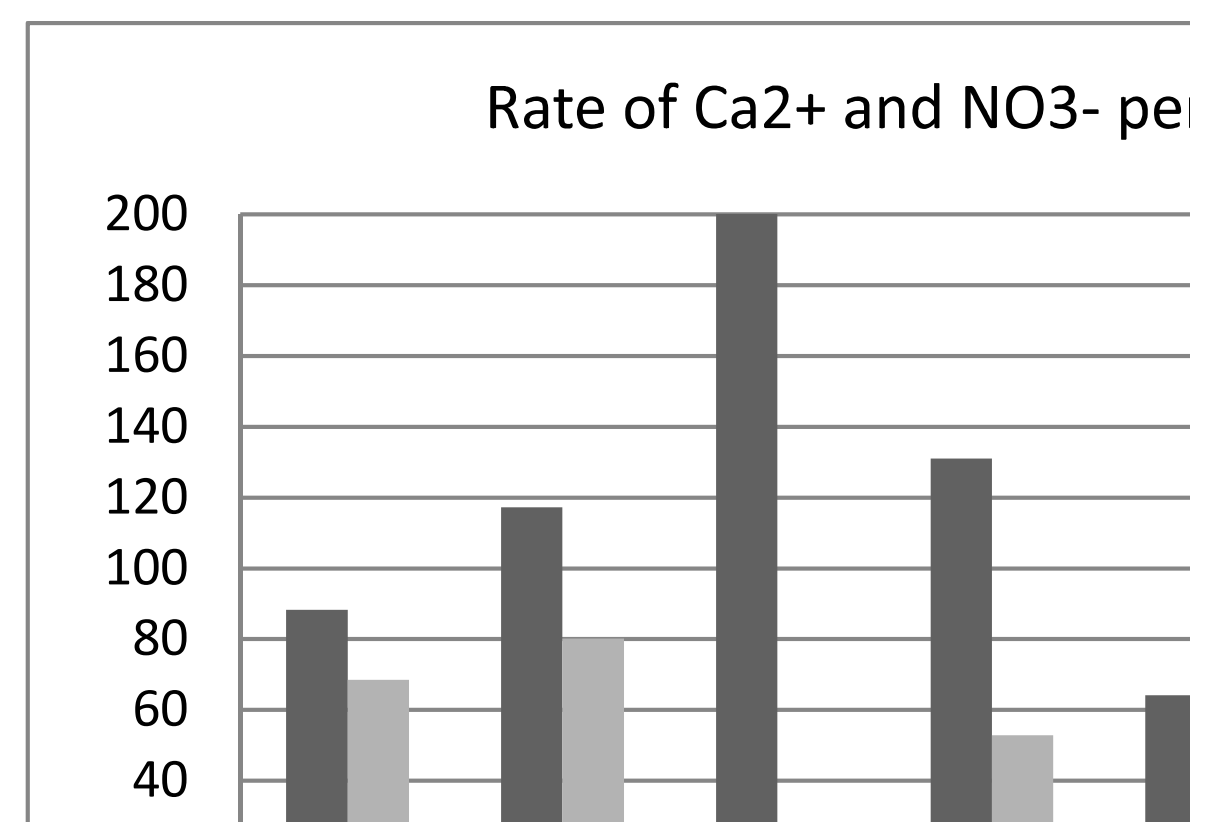

Figure 3: Rates of $\mathrm{Ca}^{2+}$ and $\mathrm{NO}_{3}{ }^{-}$per district. 


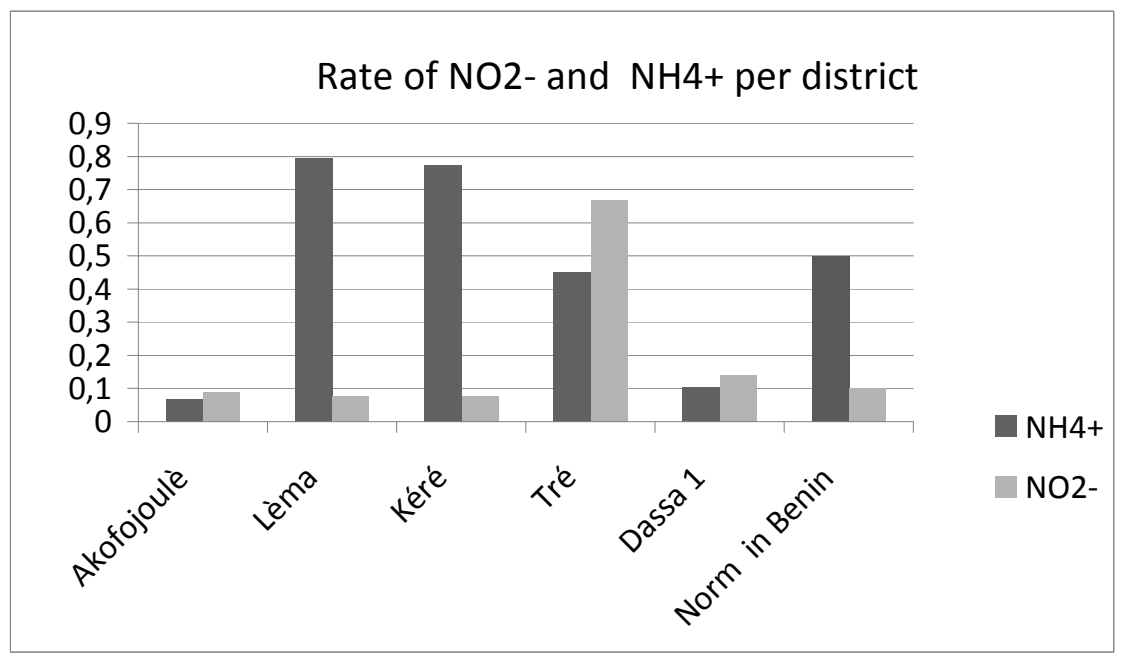

Figure 4: Rates of $\mathrm{NO}_{2}{ }^{-}$and $\mathrm{NH}_{4}^{+}$Per district.

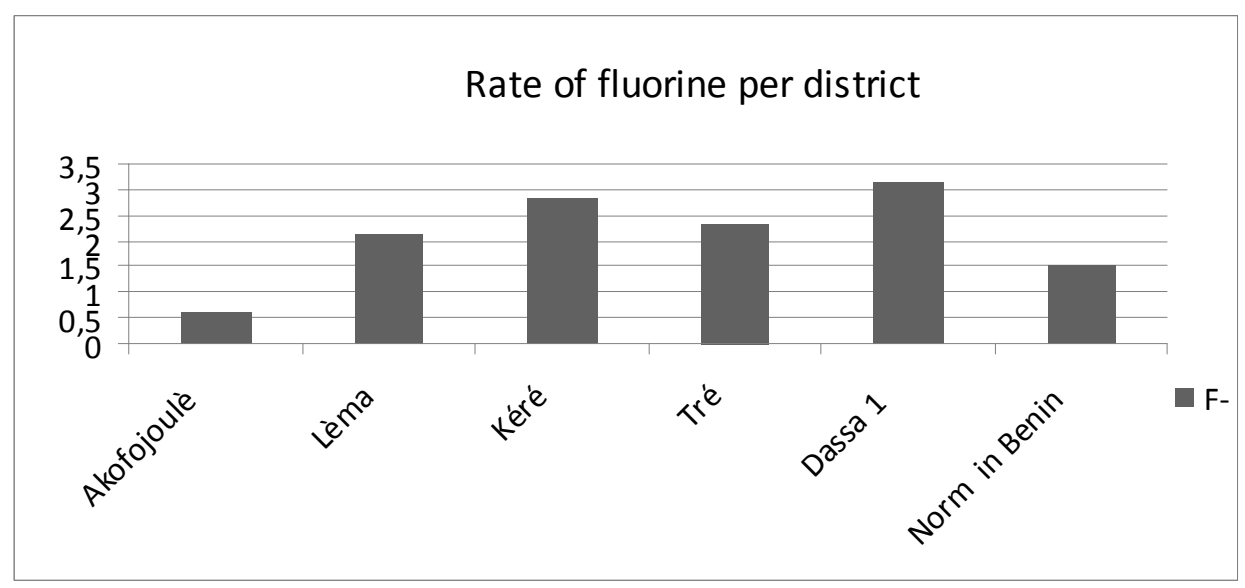

Figure 5: Rate of fluorine per district.

\section{DISCUSSION}

The $\mathrm{pH}$ variations in waters from Dassa-Zoumè confirm Dovonon's researches (Dovonon et al., 2011) which showed variations from 6.4 to 7.08 with an average of 6.83. $\mathrm{pH}$ less than $<6.5$ is able to increase the toxicity of the cyanide complex. Excessive production of soluble salt water makes the water unusable due to corrosive nature. Similarly, the alkaline $\mathrm{pH}$ (more than 6.5) increases the $\mathrm{NH}^{4+}$ toxicity in water. These waters meet the standards and recommendations of the WHO (6.5 to 8.5) and are therefore safe for consumption (WHO, 2002). Fluorine levels fluctuate greatly in the municipality, between 0.29 and $4.3 \mathrm{mg} / \mathrm{l}$ with an average of $1.87 \mathrm{mg} / \mathrm{l}$. The analysis reveals that the lowest rates are in the district of Akofodjoule with values ranging from 0.29 $\mathrm{mg} / \mathrm{l}$ to $0.98 \mathrm{mg} / \mathrm{l}$, while the highest rate is obtained in Kere precisely at Okéméré with a value of $4.3 \mathrm{mg} / \mathrm{l}$. Apart from the district of Akofodjoulé, average fluorine contents are higher than the recommended standard for 
drinking water (WHO, 2002) in the districts of Dassa-Zoumè 1, Tré, and some samples from Kere (Okéméré, Tangbe) and Lema (Zankoumadon). These values also corroborate the findings of Dovonon (2011), which revealed an average content of 1.63 $\mathrm{mg} / \mathrm{l}$. Some works in the Ethiopian Rift Valley have shown that the high fluorine contents people exposed to are of natural origin. It is reportedly related to the dissolution of volcanic materials (base) that release fluorine in the ground water system. (Jha et al., 2011; Ayenew, 1998; Gossa, 2006).

Researches done by Rango et al. (2012) in the same area have proven that this dissolution can be explained not only by high levels of fluorine, but also by high alkalinity ( $\mathrm{pH} \geq 8.9$ ), concentrations of $\mathrm{Na}, \mathrm{HCO}_{3}$ and high salinity in waters. But this development is inversely proportional to the $\mathrm{Ca}^{2+}$, rate which decreases. This report highlights the process of cation exchange between the rocky material and water. During the dissolution, the $\mathrm{Na}^{2+}$ released in waters by the minerals of the rock matrix is compensated by settling $\mathrm{Ca}^{2+}$, content down in the water.

In all water samples from the district of Akofodjoulé where $\mathrm{F}^{-}$contents are below standard, the contents of $\mathrm{Ca}^{2+}$, are also below standard. On the contrary, in districts of Dassa1 and Tré, standards are exceeded for both $\mathrm{F}$ and $\mathrm{Ca}$. Therefore the cation exchange process is opposite to observations made in the Ethiopian Rift Valley. It could be linked to the mineralogy of the materials consisting essentially of calcium feldspar. Only the district of Lema, where there has been an $\mathrm{F}$ pollution in Zankoumadon, presents average rates of, $\mathrm{NH}^{4+}, \mathrm{NO}_{3}^{-}$, and $\mathrm{NO}_{2}^{-}$exceeding accepted standards.

\section{Conclusion}

Waters in Dassa-Zoumè have been subjected in recent years to a chemical pollution with fluorine. It impairs its quality as a source of life. To meet the needs for this commodity that is fast becoming rare due to population growth and make good quality water available, options for the treatment of these contaminated waters should be considered so as to achieve the desired sustainable use of natural resources in Benin.

\section{COMPETING INTERESTS}

The authors declare that they have no competing interest.

\section{REFERENCES}

Craig L, Lutz A, Berry K, Yang W. 2015. Recommendations for fluoride limits in drinking water based on estimated daily fluoride intake in the upper East region, Ghana. Sci Total Environ, 1(532):127137. DOI: 10.1016/j.scitotenv.2015. 05.126. Epub2015 jun8.

Ene I, Astrid S, Enn K. 2014. Reducing Exposure to High Fluoride in Drinking ater Estonia- A Countrywide Study. Inter. J. Envi Res Public Health, 11(3): 31323142. DOI: $10.3390 /$ ijerph 110303132.

World Health Organization (Genèva). 2002. Environmental Health Criteria luorides. Geneva: WHO. Disponible sur : URL:<http ://www.inchem.org/document s/ehc/ehc/ehc227.htm>. [Consulté le 26 Mai 14].

Cairncross S, Feachem R. 1993. Environmental Health Engineering in the Tropics: An Introductory ( $2^{\text {nd }}$ edn). John Wiley and Sons: Chichester.

Arif M, Husain I, Hussain J, Kumar S.2013.Assessment of fluoride in groundwater level and prevalence of dental fluorosis in Didwana block of Nagaur district, central Rajasthan, India. Int. J. Occup Environ. Med., 4: 178-184.

Yigezu, Israel. 2013. The Challenges and Prosects of Potable Water Mangement at Edja Woreda- Ethiopia. Anchor Academic Publishing: Hamburg.

Bronckers AL, Lyaruu DM, Den Besten PK.2009. The impact of fluoride on ameloblasts and the mechanisms of enamel fluorosis. J. Dent. Res., 88(10): 877-893. DOI: $10.1177 / 0022034509343280$. 
Dovonon L, Soclo H, Gbaguidi M, Youssao Y. 2011. Use of charred bones in the defluoridation of contaminated water: Experimental determination of the calcination temperature and the optimum size of the bones. Int J Biol Chem Sci., 5(4): $1712-1726 . \quad$ DOI : http://dx.doi.org/10.4314/ijbcs.v5i4.34

Institut National de la Statistique et de l'Analyse Economique (Bénin). 2002. Recensement générale de la population humaine 3.INSAE : Bénin. Balakrishnan A, Jonathan R, Benin P, Kuumar A. 2013.Evaluation to determine the caries remineralization potential of three dentifrices: An in vitro study. $J$ Conserv Dent., 16(4): 375-379. [En ligne]. Disponible sur: URL :<http://www.ncbi.nlm.nih.gov/pub $\mathrm{med} /$ ?term=Evaluation+to+determine+the + caries+remineralization+potential+of+th ree+dentifrices $\% 3 \mathrm{~A}+\mathrm{An}+\mathrm{in}+\mathrm{vitro}+$ study >. [Consulté le 26/04/2014]. DOI: 10.4103/0972-0707.114347.

Jha SK, Mishra VK, Sharma DK, Damodaran T. 2011. Fluoride in the environment and its metabolism in humans. Rev Environ Contam Toxicol., 211:121-142. DOI:10.1007/978-1-4419-8011-3_4.
Ayenew T. 1998. The hydrogeological system of the Lake District Basin, Central Main Ethiopian Rift. These: Chir Dent: Netherlands: FUA.

Gossa T. 2006. Fluoride contamination and treatment in The Ethiopian Rift Valley. World Water Forum, 4 Addis Ababa. Ethiopia, MWR.

Rango T, Kravchenko J, Atlaw B, McCornick PG, Jeuland M, Merola B, Vengosh A. 2012. Groundwater quality and its health impact: An assessment of dental fluorosis in rural inhabitants of the Main Ethiopian Rift. Envi Int., 43: 37-47. DOI: 10.1016/j.envint.2012.03.002.

Egboou P. 2008. Etat des lieux des collectifs, plateformes et réseaux d'organisation de la société civile du secteur eau et assainissement dans 7 pays de l'Afrique de l'ouest et du centre: Rapport Benin. Bénin : ONG Coalition-Eau ; [En ligne]. Disponible sur: URL : $<$ http:// www.coalition-eau.org/wp-content/ uploads/Rapport-Benin-CoalitionEau.pdf>. [Consulté le 26/05/2014]. 